\title{
Fish resource exploitation in the southern Atlantic coast of the Iberian Peninsula: A view from the traceological analysis of flaked stone tools (sixth- fourth mill. cal BCE)
}

\author{
Ignacio Clemente-Conte ${ }^{\mathrm{a}, *}$, Niccolò Mazzucco ${ }^{\mathrm{a}}$, Joaquina Soares ${ }^{\mathrm{b}, \mathrm{c}}$, Carlos Tavares da Silva ${ }^{\mathrm{d}}$, \\ José Ramos Muñoz $^{\mathrm{d}}$, Eduardo Vijande Vila ${ }^{\mathrm{d}}$, Juan Jesus Cantillo ${ }^{\mathrm{e}}$, Manuel Montañés ${ }^{\mathrm{f}}$ \\ ${ }^{a}$ Archaeology of Social Dynamics, CSIC - Institución Milá y Fontanals (IMF), Barcelona, Spain \\ ${ }^{\mathrm{b}}$ MAEDS-Museum of Archaeology and Ethnography of the District of Setúbal, Setúbal, Portugal \\ ${ }^{\mathrm{c}}$ UNIARQ Centre of Archaeology of the University of Lisbon, Portugal \\ ${ }^{\mathrm{d}}$ Departamento de Historia, Geografía y Filosofía, Facultad de Letras, Universidad de Cádiz, Cádiz, Spain \\ e Ayuntamiento de Vejer de la Frontera, Cádiz, Spain \\ ${ }^{\mathrm{f}}$ GEHA Arqueología SCPSN, Spain
}

\section{A R T I C L E I N F O}

\section{Keywords:}

Fish processing

Use-wear

Mesolithic

Neolithic

Iberian peninsula

\begin{abstract}
A B S T R A C T
In this paper, we provide new data on fish resource exploitation during the Mesolithic and Neolithic period on the Atlantic coast of the Iberian Peninsula. Evidence from four different sites is presented: Vale Marim I (end of the seventh/beginning of the sixth millennium cal BCE) and Vale Pincel I (2nd and 3rd quarters of the sixth millennium cal BCE), both located on the southwestern Portuguese coast, and La Esparragosa and SET Parralejos (fourth-third millennia cal BCE), both located on the southern Spanish coast. The analysis of the lithic assemblages by means of use-wear analysis provided evidence of fish-processing activities. The analysis of the archaeological tools has been based on a renewed experimental framework for fish-related use-wear traces. Despite data being still scarce and fragmentary, this study points out the necessity of a more integrating approach, including traceological analysis in the framework of a broader research on prehistoric fishing.
\end{abstract}

\section{Introduction}

The Mesolithic-Neolithic transition in the southwestern Iberian Peninsula has been widely debated during the last decades (Carvalho, 2002, 2018; Soares and Tavares, da Silva, 2004; Ramos, 2005; Ramos et al., 2006; Cortés et al., 2012; Diniz and Neves, 2018). In this area, the first Neolithic populations largely settled in enclaves located in areas previously occupied by Mesolithic hunter-fisher-gatherer groups that depended on a broad range of coastal and terrestrial resources (Valente and Carvalho, 2009; Bicho et al., 2010; Ramos et al., 2011; Cortés et al., 2012; Soares and Tavares da Silva, 2018). Around 5500-5000 cal BCE, in southern Portugal Neolithic communities began a farming economy based on the exploitation of domesticated plants and animals, with ovicaprids and free-threshing wheat being the most frequent domesticated species in the archaeological record (Carvalho et al., 2013; Peña-Chocarro et al., 2014; Davis and Simões, 2016; López-Dóriga, 2015; Soares et al., 2016). Soon after the appearance of Neolithic complexes, Mesolithic presence in the area would rapidly decline for reasons still largely unknown. Much of the debate has been focused on the relationship between the Mesolithic and Neolithic communities, in terms of process of demographic absorption (Carvalho, 2002; Bicho et al., 2017), process of acculturation (Gonçalves et al., 2008), cultural osmosis (Tavares da Silva and Soares, 2007), and process of technical transfers (Marchand, 2005; Marchand and Manen, 2010). In this context, patterns of subsistence and, in particular, the dependence on marine and estuarine food sources has often been called into question as one of the key elements for understanding the Meso-Neolithic transition. While some scholars have pointed out a clear break in the subsistence systems between the two periods (Zilhao, 2003; Cortés et al., 2012; Dean et al., 2012; Carvalho, 2018), others defend a more nuanced transition and the existence, at least on some sites, of a continuity in the modes of resource exploitation (Soares, 1996; Ramos et al., 2006, 2011; Bicho et al., 2017). This would be especially true for shellfish and fish species. Nevertheless, one of the main limitations of

\footnotetext{
* Corresponding author.

E-mail addresses: ignacio@imf.csic.es (I. Clemente-Conte),nmazzucco@imf.csic.es (N. Mazzucco), cea.maeds@amrs.pt (J. Soares),

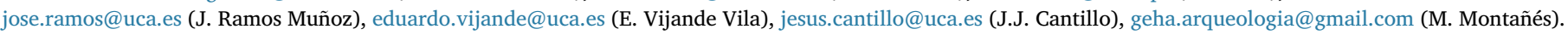


such approaches is the limited amount of data on fishing practices of Meso-Neolithic populations. While shellfish exploitation is rather well known thanks to the abundant research on Mesolithic and Neolithic shell middens (Soares, 1996; Soares et al., 2005-2007; Soares, 2013; Bicho et al., 2010), available data on fishing practices is much scarcer (LeGall et al., 1992; Marques-Gabriel, 2015). Archaeological evidence of fish consumption and exploitation are indeed more rarely and discontinuously detected, due to problems of remains preservation and recovery. It is therefore very difficult to evaluate patterns of continuity or discontinuity relying on such fragmentary record.

One way to fill these gaps of the record could be to focus on the technology associated to fish exploitation and consumption. The presence of artefacts associated with fishing practices is a good indicator that can complete or even provide an alternative evidence of fishing when fish remains have not been recovered or preserved. Hooks, harpoons and fragments of fish traps represent a good example of these types of artefacts and a very clear testimony of fishing (MoundreaAgrafioti, 2003; Marijanović, 2009; Komšo and Čuka, 2014; ClementeConte et al., 2013; 2016; Lozovski et al., 2013). Spatulas and other bone tools can also be associated with fishing or to fish processing activities, even if their recognition as fishing gear is far more complicated (Clemente-Conte et al., 2002; Rodríguez Santana et al., 2008; Arrighi et al., 2016).

Flaked stone tools can as well provide information on this topic. Pioneer experimental studies demonstrated that use-wear traces from fish scaling and processing presented characteristic features (Moss, 1983; Gijn, 1984/85/86), distinguishable from other use-wear categories such as butchering, bone or hide working. Successive experimental works confirmed that use-wear traces from fish processing could be quite distinctive (Clemente-Conte et al., 2010; García Díaz and Clemente-Conte, 2011). More recently, an integrated approach of usewear and protein residue analysis has as well provided interesting results for Scandinavian lithic assemblages (Högberg et al., 2009), while a brand recent experimental approach through FTIR microspectroscopy (Monnier et al., 2018) suggests that this technique can also provide insights into fish processing tools, despite its archaeological applicability still has to be proved.

The aim of this article is to provide additional data on the MesoNeolithic subsistence practises in the southwestern Iberian Peninsula, through the use-wear analysis of flaked stone tools. The study of coastal prehistoric societies led us to a revaluation of the methodological framework for interpretation of stone tool function. Therefore, basing on recent experimental works, a review of the available knowledge on fishrelated use-wear traces will be provided. The results of the analysis of several flaked stone assemblages will be therefore presented. The sites taken into analysis are: Vale Marim I (Late Mesolithic) and Vale Pincel I (Early Neolithic) both located in the Alentejo Coast (Portugal), and La Esparragosa and SET Parralejos (Middle Neolithic) in the Bahia of Cádiz (Spain) (Fig. 1). The contribution of traceological analysis is especially relevant in those contexts in which the conservation of organic remains is generally poor, making difficult obtaining data on palaeoeconomic behaviours.

\section{Materials and methods}

Traceological analysis has been carried out with a stereoscopic microscope Leica AZ16 $(10 \times-60 \times)$ and a reflected-light microscope Leica DM2500 $(50 \times-400 \times)$, following a standard procedure. Archaeological tools have been cleaned with alcohol before the analysis. Experimental tools, after their use, were cleaned with water and alcohol, and afterwards with a solution of $1 \%$ hydrogen peroxide and placed in the ultrasonic tank to remove the most superficial residues.

\subsection{Archaeological sites and studied samples}

\subsubsection{Vale Marim I}

The site of Vale Marim I has been discovered and excavated by Tavares da Silva and Soares in the early 1980s. It is located in the Sines harbour domain (southwest Portuguese coast, Alentejo region). Excavation works revealed a high concentration of dwelling structures, and flaked stone remains. The site is interpreted as a large base camp, occupied almost all year-round (Soares and Tavares da Silva, 2018). Flaking activities and artefact production probably played a major role in this site (Soares et al., 2017). Site occupation has been dated to the Late Mesolithic thanks to a series of radiocarbon dates on charcoal samples that calibrated to 2-sigma give the time span of $6075-5840 \mathrm{cal}$ BCE.

\subsubsection{Vale Pincel I}

The site of Vale Pincel I is located on the southwest Portuguese coast, few hundred metres away from the above-mentioned Vale Marim I. It is as large open-air site, covering a surface of about 10 ha. Domestic structures of diverse functionality have been detected during the excavation works, suggesting the existence of large and stable human occupation (Soares et al., 2016). Impressed Ware with very scarce Cardial motifs, filiated in the Pré-Franco-Iberian Cardial Neolithic (see Guilaine, 2017: Fig. 6; Soares and Tavares da Silva, 1979: p. 24) had been recovered from the excavations. Traceological analysis has revealed the presence of sickle blades used for harvesting cereals (Soares et al., 2016). Occupational phases have been dated thanks to a series of radiocarbon dates on charcoal. The greater probability density for site occupation is given for the interval ca. 5640-5380 cal BCE (Tavares da Silva and Soares, 2015).

\subsubsection{SET parralejos}

The site of SET Parralejos is located in Vejer de la Frontera (Cádiz, Andalucía, Spain), at an altitude of $182 \mathrm{~m}$ a.s.l., in one of the last hills of the Subbaetic System. Its current distance from the coastline is of about $9.5 \mathrm{~km}$. The site has been discovered in 2008 (Villalpando and Montañés, 2009), and until now two excavation campaigns have been carried out, in 2008-2009 and in 2012. The site is one of the many 'campos de silos' that characterise Andalucía at the end of the Neolithic period. Over an area of about $3000 \mathrm{~m}^{2}, 59$ pits have been documented of which 34 have been fully excavated (Villalpando and Montañés, 2016). Radiocarbon dating suggests an occupation between $c a .3520$ and $3015 \mathrm{cal} \mathrm{BCE.}$

\subsubsection{La Esparragosa}

The site of La Esparragosa is few kilometres away from the village of Chiclana de la Frontera (Pérez et al., 2005; Vijande, 2006, 2008; Ramos et al., 2008, 2010). It is situated on a plateau beside the Iro River, at about $30 \mathrm{~m}$ a.s.l. A surface of $40 \times 10 \mathrm{~m}$ has been excavated in two campaigns (2002-2003). The site is characterised by the presence of eight pit structures and one burial. The silos are semicircular in shape with different sections, both bell-bottomed and cylindrical types, whose diameter varies between 1 and $1.20 \mathrm{~m}$ and with a depth of $1-1.40 \mathrm{~m}$. These structures appeared filled with faunal and malacological remains, lithics and pottery fragments (Vijande-Vila et al., 2018). Four dates have been obtained from charcoal samples and two dates by TL from pottery associated with the burial, indicating an occupation between $c a$. 3020 and 2920 cal BCE.

\section{Experimental framework}

\subsection{Fish processing use-wear traces: insights from experimentation}

Several authors have referred to fish-related use-wear traces in their works. Semenov (1964), Keeley (1980) and Vaughan (1985), refer to experiments on fish processing, however, without detailing the 


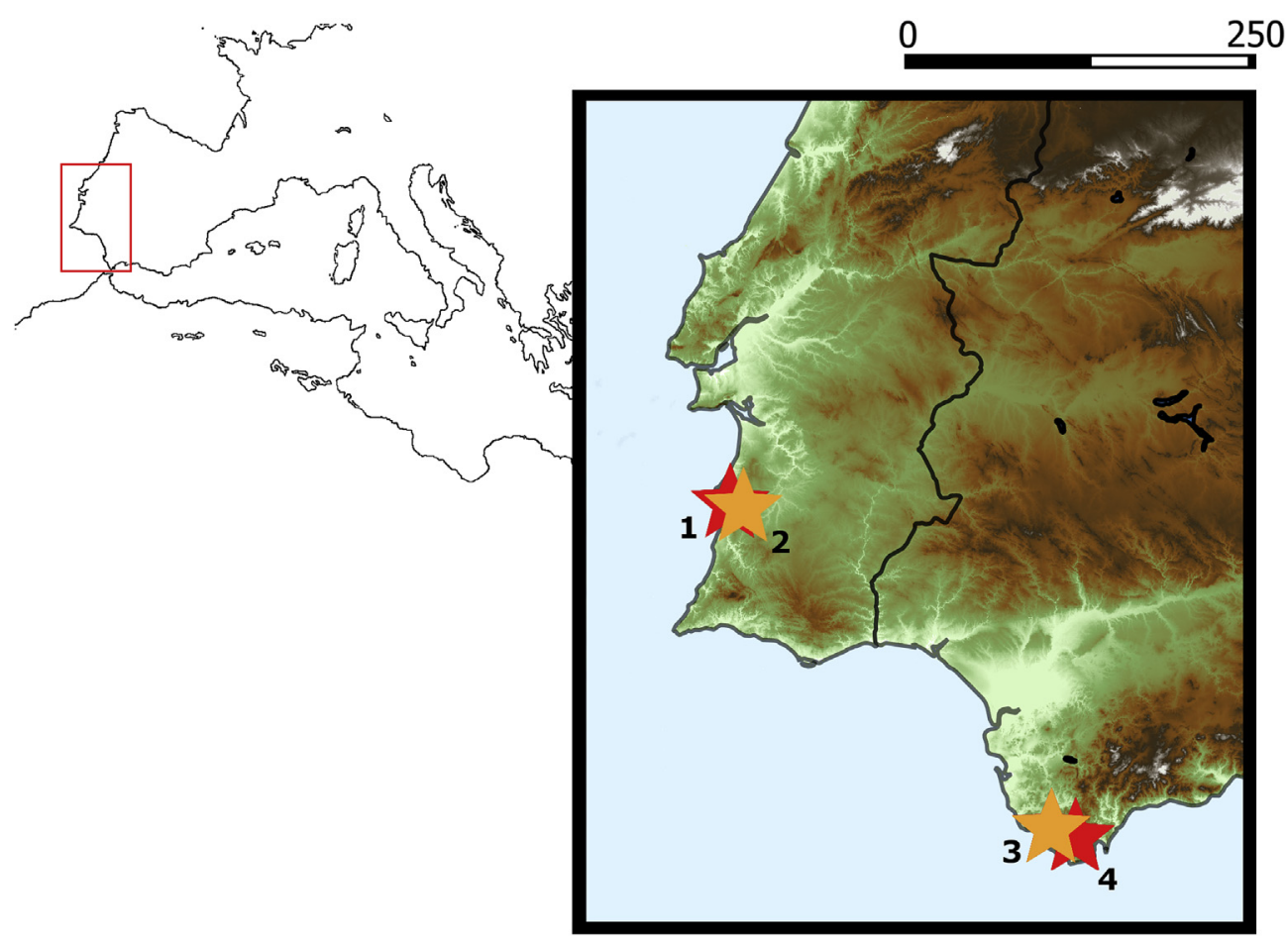

Fig. 1. Geographical framework. The stars indicate sites. 1) Vale Marim I; 2) Vale Pincel I; 3) SET Parralejos; 4) La Esparragosa.

microscopic and macroscopic features of this type of use-wear trace, including them within a broader category of 'meat' or 'butchering' usewear traces. More detailed descriptions are provided by AndersonGerfaud, (1981), Moss (1983), Plisson (1985), Morin (2004), and Iovino (2002), and more recently Robson et al. (2018). Matt polish bands with striations are described as the main characteristic features. Nevertheless, the most detailed attempt to characterise use-wear traces from fish processing activities has been made by Gijn (1984/85/86, 1989). Different phases of fish cleaning and processing were reproduced separately: scaling, gutting and head cutting. The resulting traces were defined as following:

- Scaling: a dull and flat polish, characterised by rough and greasy appearance. The polish was often discontinuously distributed along the used edge. Only when the fish has very firm scales, a continuous and well-developed band of polish develops. Edge scarring if present, consists of irregularly distributed edge removal.

- Gutting: a rough, dull and flat polish. The polish is distributed in a more or less band near or somewhat behind the working edge, depending on the cases. Striations parallel to the direction of working movement are as well documented. An irregular scalar chipping of the edge is visible.

- Head cutting: a band of polish, dull and rough, is visible. Occasionally bright and smooth spots resulting from the contact with fish bone are observable. Edge scarring consists of a pattern of discontinuous fractures.

Within the framework of the current research, a new experimental program was carried out. The aim of this new experimental session was: 1) to corroborate previous experimental results; 2) to test the difference between hand-held and hafted tools; 3) to enlarge our experimental reference collection.

Seven different tools have been produced. All of them were made on a fine-grained chert of the Donbass Basin, microscopically similar to the chert exploited in the archaeological sites in study. Two elongated flakes and eight blades were used, all of them unretouched. Six tools were hand-held, while four blades were broken into fragments and hafted onto a straight wooden handle, forming a roughly straight cutting edge (Fig. 3). This hafting mode has been based on a hypothesis derived from the study of the archaeological materials, which often show reduced dimensions and would be more easily used hafted. Hafting allows as well to apply more pressure on the fish and thus cleaning tasks result more effective.

Small and medium size marine species were processed: striped red mullet (Mullus surmuletus - Linnaeus, 1758), common sole (Solea vulgaris - Linnaeus, 1758), European sea bass (Dicentrarchus labrax - Linnaeus, 1758), gilt-head sea bream (Sparus aurata - Linnaeus, 1758) and Atlantic pomfret (Brama brama - Bonnaterre, 1788). The aim was to test the differences in the wear formation process. Although no differences were observed in the use-wear resulting from filleting, gutting and headcutting tasks from different species, scaling traces developed more quickly when working gilt-head sea bream, a species with more resistant scales.

Twenty-three tasks were carried out at different time intervals (10, 15, 30, 45 60, $90 \mathrm{~min}$ ) (Table 1). After each time interval, lithic edges were observed to document the process of wear development. In some cases, tasks were carried out singularly (eight for gutting, nine for scaling and three for decapitating). However, three tools were used to carry out the whole process (scaling, gutting, and decapitating), as it would seem archaeologically sounder to use the same tool for the entire cleaning process.

Results fundamentally confirm the description already made by previous authors:

- Scaling: use-wear traces are mainly formed on the face in contact with the fish scales, while micro scarring mainly occurs on the opposite face. Edge rounding is moderate, while micro polishes are characterised by a rough and greasy appearance, adapted to the topography of the flint (Fig. 2, C\&D; Fig. 3, F).

- Head cutting: use-wear traces are equally formed on both sides, as the angle of contact between the working edge and the material is roughly perpendicular. As a result of the contact with the skeletal parts of animal, the polish appear rather flat, compact, forming a band along the edge, not penetrating into the inner surface (Fig. 2, 
Table 1

Overview of the experimental works carried out. Seven different experiments, corresponding to 14 different actives zones were realized.

\begin{tabular}{|c|c|c|c|c|c|c|}
\hline TOOL_NUMER & TOOL_TYPE & HAFTING MODE & ACTIVE ZONES & FISH SPECIES & ACTIVITY & TIME \\
\hline \multirow[t]{7}{*}{ EXP_1 } & Unretouched elongated flake & Hand-held & 1 & Gilt-head sea bream (Sparus aurata) & Head cutting & 5 \\
\hline & & & & & & 10 \\
\hline & & & & & & 15 \\
\hline & & & 2 & & Scaling & 15 \\
\hline & & & & & & 30 \\
\hline & & & & & & 45 \\
\hline & & & & & & 60 \\
\hline \multirow[t]{3}{*}{ EXP_2 } & Unretouched blade & Hand-held & 1 & & Filleting and gutting & 15 \\
\hline & & & & & & 30 \\
\hline & & & & & & 45 \\
\hline EXP_3 & 4 unretouched blade fragments & Hafted in a straight wooden handle & 4 & & Mixed movement & 60 \\
\hline EXP_4 & Unretouched blade & Hand-held & 1 & Common sole (Solea vulgaris) & Mixed movement & 90 \\
\hline EXP_5 & Unretouched blade & Hand-held & 1 & Striped red mullet (Mullus surmuletus) & Mixed movement & 60 \\
\hline \multirow[t]{7}{*}{ EXP_6 } & Unretouched blade & Hand-held & 1 & European sea bass (Dicentrarchus labrax) & Filleting and gutting & 15 \\
\hline & & & & & & 30 \\
\hline & & & & & & 45 \\
\hline & & & 2 & & Scaling & 15 \\
\hline & & & & & & 30 \\
\hline & & & & & & 45 \\
\hline & & & 3 & & Gutting & 5 \\
\hline \multirow[t]{3}{*}{ EXP_7 } & Unretouched flake & Hand-held & 1 & Atlantic pomfret (Brama brama) & Scaling & 10 \\
\hline & & & & & & 30 \\
\hline & & & 2 & & Filleting and gutting & 15 \\
\hline
\end{tabular}

F; Fig. 3, E, H). However, a greasy polish with a less compact distribution might as well occur, in the interior areas.

- Filleting and gutting: both filleting and gutting show quite similar traces. They produce a combination of polish characterised by a rough and greasy appearance (produced by the contact with meat and skin parts) and spots of more compact and flat polish (produced by the contact with bone parts). Fine striations in the inner surface often occur because of the contact with fish vertebrae during gutting phases (Fig. 2G and H; Fig. 3A-E \& G).

All performed tasks show quite similar traces, although subtle differences can be remarked. Tools that were used to carry out all the different steps show a combination of the various use-wear traces; in our option, it is very difficult to distinguish the traces produced by each individual task, especially in archaeological specimens. Nevertheless, at a more general level, fish traces appear quite distinctive because of the combination of their wear patterns, and should be separated from butchering and meat cutting use-wear traces.

\section{Results}

\subsection{Archaeological evidence}

\subsubsection{Vale Marim I}

The traceological analysis has been carried out over a relevant sample of flaked stone tools. 1213 artefacts have been analysed from a total assemblage of 7614 flaked lithics on chert raw materials. Stone knapping is locally carried out using nodular chert-types available in the regional context. All stages of core reduction are well-represented on site, and a bladelet-oriented production has been recognized (Soares et al., 2017).

The traceological analysis has revealed a low ratio of used tools. Of the analysed sample, only 132 used edges have been detected, which means a high percentage of unused edges. This pattern is not a result of bad preservation conditions; lithic edges and surfaces show very good state of preservation. Vice versa, the obtained data fit the hypothesis of Vale Marim I being a production centre. Flaking activities might have taken place during intervals of downtime in anticipation of a specific peak period of resource exploitation (Kuhn, 1989). In this sense, it is remarkable that an area specifically destined to knapping activities has been identified. Polished chisels, a concentration of flint cores and other artefacts have been recovered close to a hearth possibly used for chert heat treatment practises (Soares and Tavares da Silva, 2018). Among identified active zones (AUAs - Active Used Areas) (Fig. 4), there are traces of working processes on hard materials, such as wood, and antler/bone (25\%, $n=33$ AUAs). Use-wear traces are little developed, suggesting short duration tasks, eventually related to bone/wood tools maintenance and resharpening. Evidence of foraging and hunting practices has been obtained as well; several geometric projectiles $(25 \%$, $\mathrm{n}=33$ AUAs) show traces of having been used as tips. Finally, a large sample of tools, mostly bladelets, indicates the processing of animal carcasses $(31.1 \%, \mathrm{n}=41 \mathrm{AUAs})$. Among them, 15 tools $(11.4 \%, \mathrm{n}=15$ AUAs) show a specific association of macro edge-rounding and scarring with greasy micro polish of irregular distribution and longitudinal striations (Fig. 5) that resemble the traces experimentally obtained by fish cleaning and processing. Those bladelets have an average width of 7.3-9.6 $\mathrm{mm}$ and an average thickness of $2.5-3.5 \mathrm{~mm}$; blanks are unretouched, and acute angles are mostly selected.

\subsubsection{Vale Pincel I}

The technological and use-wear analysis has been carried out on a sample of 217 knapped chert artefacts from the lower layer of Vale Pincel I deposit (C. 2B) (Soares et al., 2016). This sample represents about the $17.4 \%$ of the whole chipped stone assemblage from the same area (1247 remains). The Vale Pincel I lithic assemblage shows a good state of conservation and more than a half of analysed samples presented well-preserved use-wear traces. The observed used zones (AUAs), reveal that a varied range of productive processes took place at the site, including tools associated with the working of mineral substance $(4.7 \%, \mathrm{n}=6)$, hunting $(13.2 \%, \mathrm{n}=17)$, and the obtaining and processing of plant raw materials $(26.4 \%, \mathrm{n}=34)$. Among these latter, the most represented activity is cereal harvesting $(24 \%, n=31)$. However, the majority of tools are related to the processing of soft substances $(44.2 \%, \mathrm{n}=57)$, related to animal carcasses butchering and cleaning. Among them, at least eight tools (6.2\%) that present a very good preservation of the micro-traces have probably been employed for fish processing activities (scaling, decapitation, gutting) (Figs. 4 and 5). Used blanks are mainly bladelets, quite standardized in size and shapes (25-35 mm length, 8-12 mm width, 3-4 mm thickness).

\subsubsection{La Esparragosa}

The traceological analysis has been carried out on a sample of items 


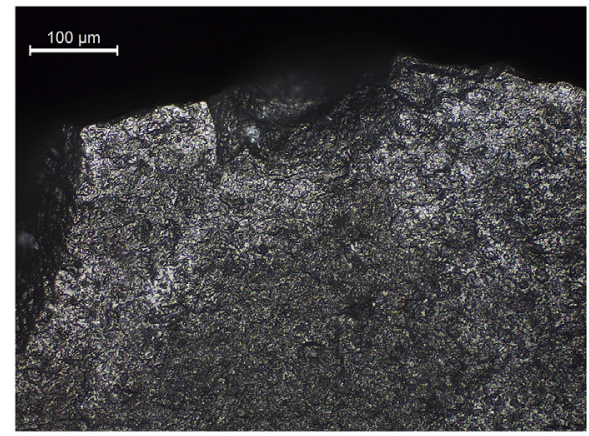

A

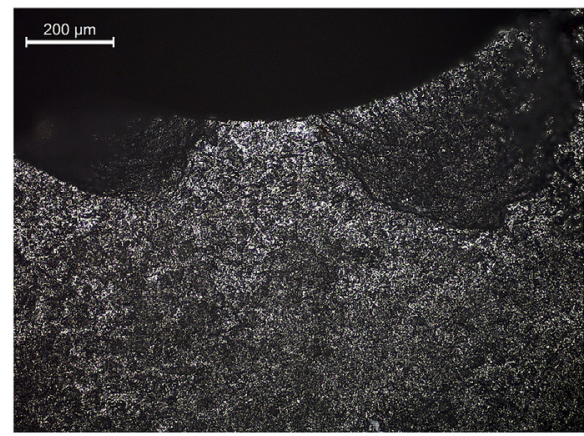

C

$100 \mathrm{X}$

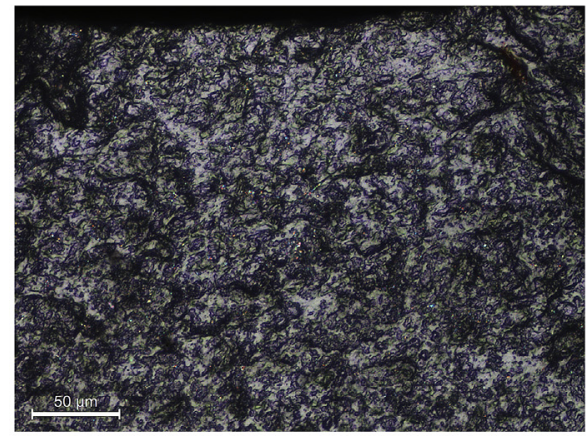

$\mathrm{E}$

400X

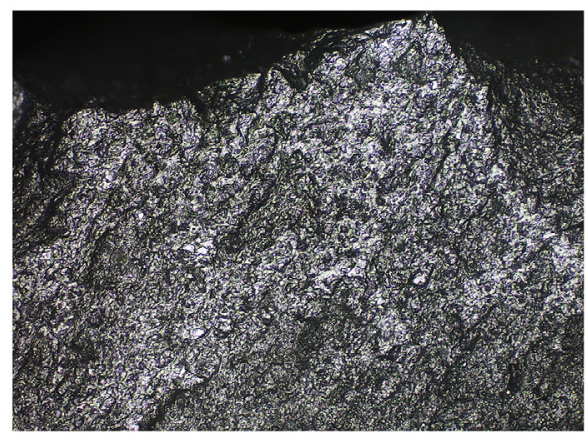

G
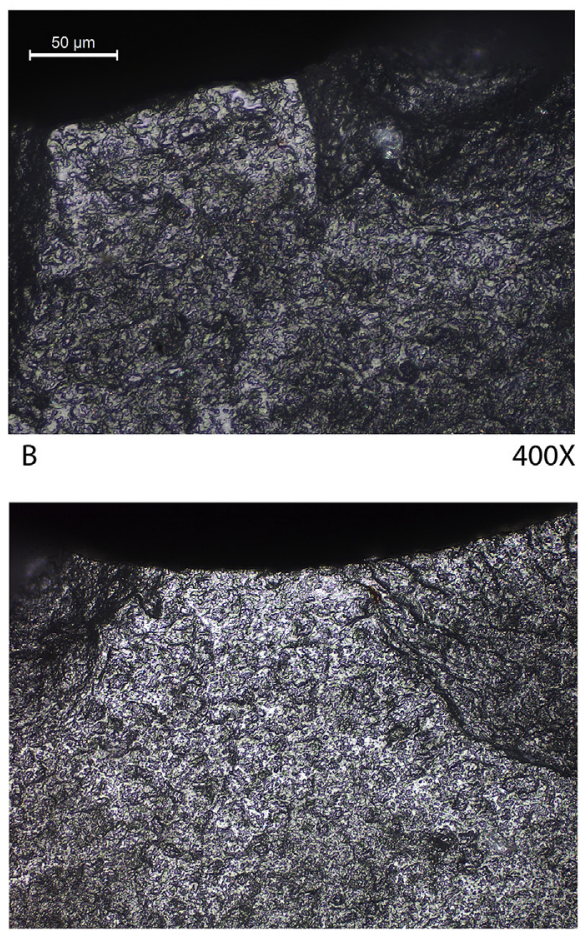

D

$200 X$

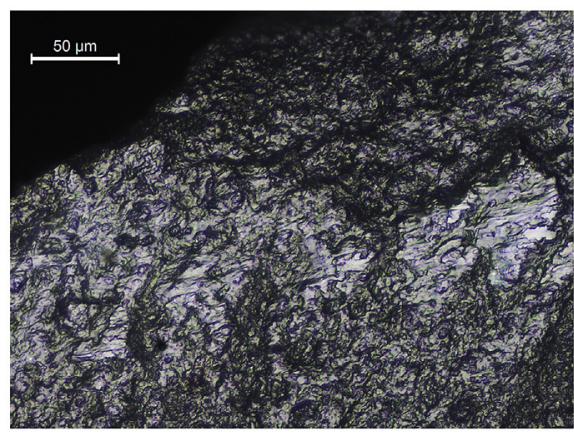

$\mathrm{F}$

$400 X$

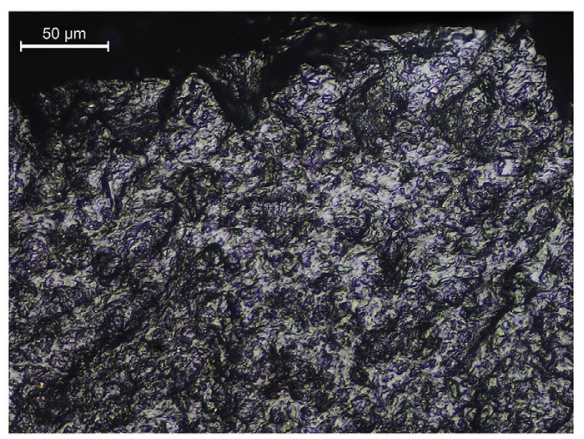

$\mathrm{H}$

$400 \mathrm{X}$

Fig. 2. Experimental use-wear analysis on lithic tools, between $100 \times$ and $400 \times$, after cleaning six gilt-head sea bream, $100 \times$. A) Greasy and rough polish, $200 \times$. See how the polish penetrates inside the edge-fracture. B) Same polish. Spots of contact with fish bone $200 \times$. C) Band of greasy and rough polish along the edge, $100 \times$. See how the polish penetrates inside the edge-fracture. D) Same polish, $100 \times$. Note the greasy and rough appearance. E) Same polish, $400 \times$. F) Striation of contact with bone material, $400 \times$. G-H) Greasy and rough polish along the edge, $200 \times$ and $400 \times$.

from the excavations campaigns of 2002-2003. Lithic production is characterised by a blade-oriented technology, including indirect percussion, pressure, and lever pressure (Morgado and Pelegrin, 2012). The analysis was focused on 388 lithic artefacts. Of them, about one half is composed of blades and blade fragments. Flake blanks represent about the $26 \%$, while the remaining remains are composed of cores, and fragments of polished tools. Microscopic observation has revealed use-wear traces on $30 \%$ of the sample, for a totality of 164 AUAs. Wood working and cereal harvesting activities are well represented $(14.2 \%$, $\mathrm{n}=24)$, followed by working tasks on hard $(10.7 \%, \mathrm{n}=18)$ and mineral materials $(1.8 \%, \mathrm{n}=3)$, as well as projectiles $(3 \%, \mathrm{n}=5)$. Nevertheless, the majority of active zones $(70.4 \%, n=119)$ have been 


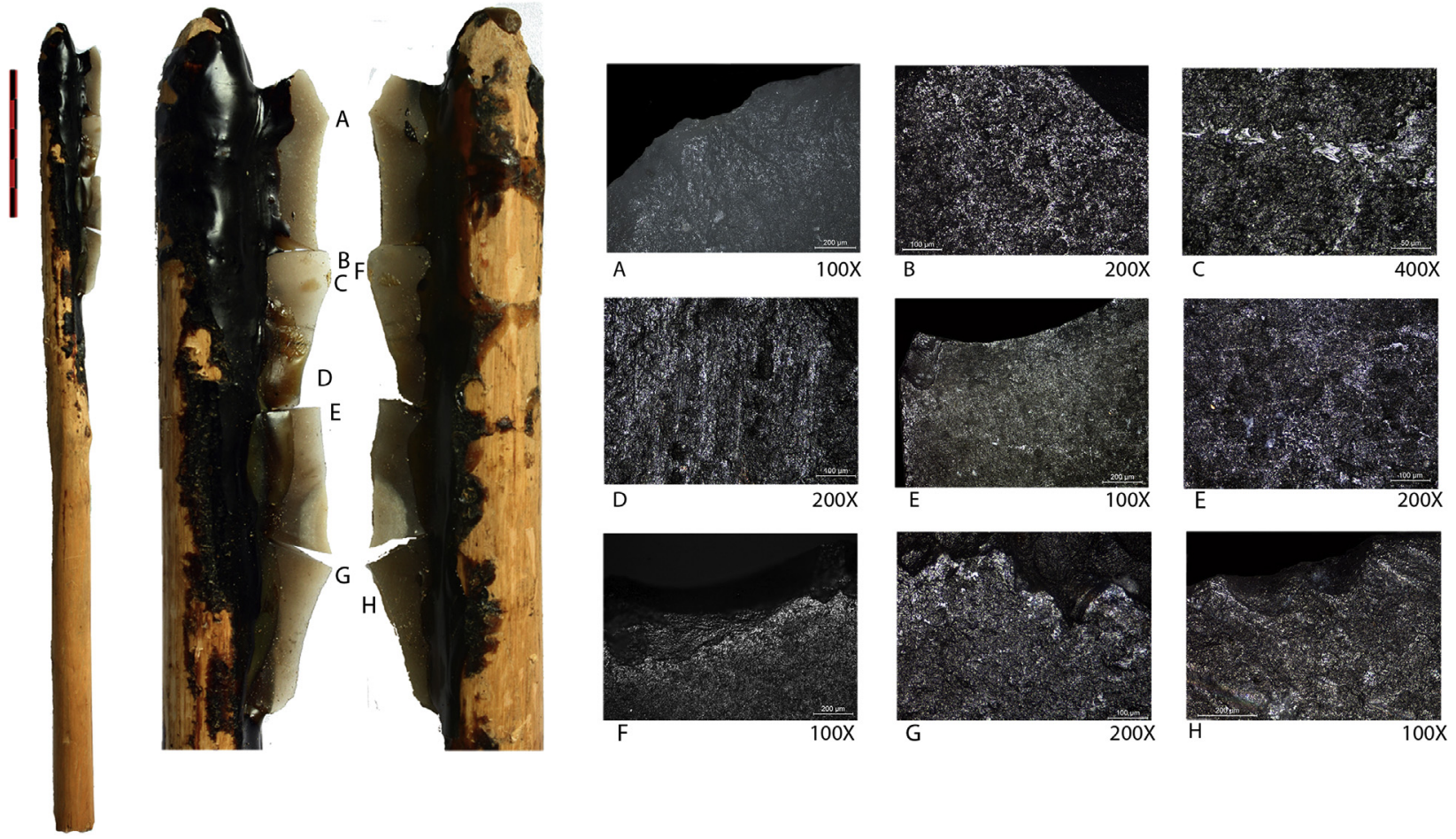

Fig. 3. Left. Experimental knife used for cleaning fish (scaling, gutting and head cutting). Right. A-B) Edge-rounding and greasy polish associated with contact with fish meat, $100 \times$ and $200 \times$.C) Striation located in the interior of the surface, associated with gutting tasks, probably produced by the contact with fish vertebra and rib bones, $400 \times$. D) Striations perpendicular to the edge, associated to fish scaling, $200 \times$. E-F) Fine striations parallel to the edge, associated to gutting and fileting tasks, $100 \times$ and $200 \times$. F-G-H) Use-wear produced from the different tasks involved in fish processing activity: band of polish along the edge, and spots of contact with bone materials.

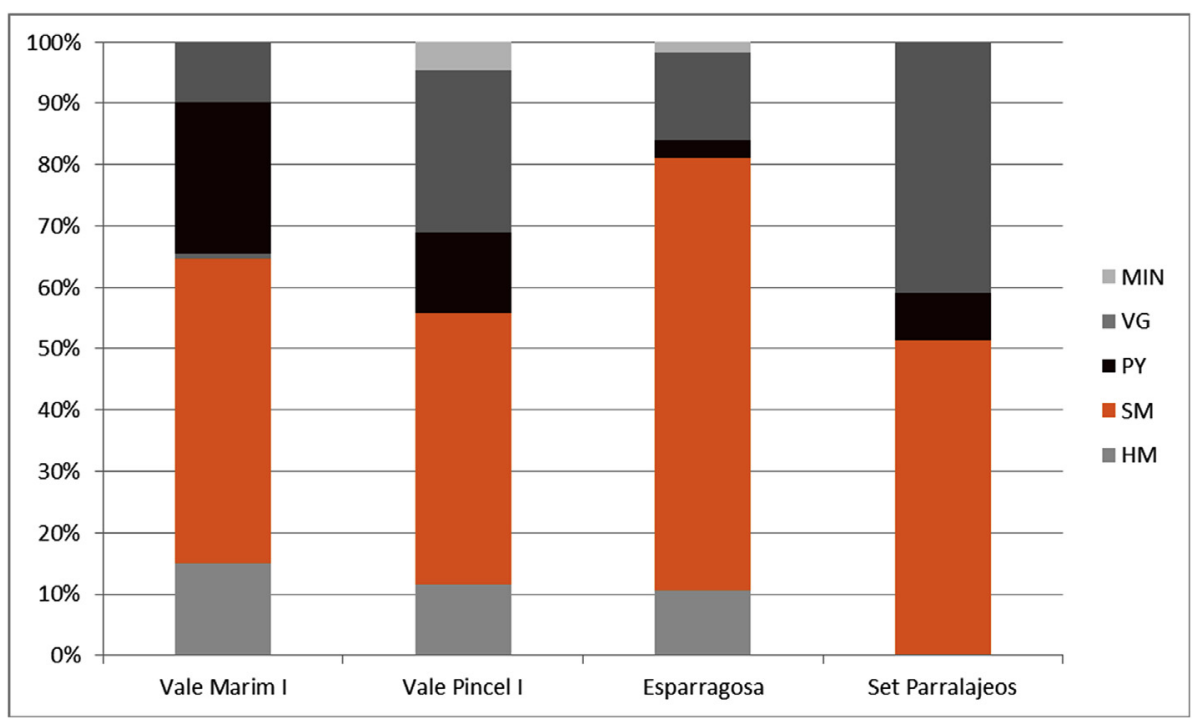

Fig. 4. Percentage of different type of use-wear recognized in the analysed assemblages. MIN: Working of mineral activities; VG: Processing and/or cutting of vegetal materials (plants, cereals, wood, etc.); PY: Traces on tools used as projectiles; SM: Cutting of soft materials, including fish; HM: Working of hard materials (bone/antler, hard indeterminate materials).

used processing animal substances, mainly using blade blanks. Among them, a very high percentage (80.6\%) presents use-wear traces showing features close to the experimental traces obtained from fish cleaning and processing (Figs. 4 and 5) (Clemente-Conte and García Díaz, 2008; Clemente-Conte et al., 2013; Mazzucco et al., 2018).

\subsubsection{SET parralejos}

The analysis has been conducted on 54 items from various pit structures. The assemblage strongly resembles the Esparragosa lithic collections from a technological point of view. Analysed blanks are mainly blades and bladelets, and in lesser extent, flakes. Of them three are bifacial-retouched points. About one half of the assemblage has been excluded from the analysis given its poor preservation conditions, while use-wear traces have been individualised on the remaining 23 items, for a total of 39 AUAs. Identified tasks are mainly related to vegetal materials $(41 \%, \mathrm{n}=16)$, of which cereal harvesting $(38 \%)$ represents the main activity while only one tool is associated with wood working, to the processing of animal carcasses $(51 \%, n=20)$, and to projectile tools $(7.7 \%, \mathrm{n}=3)$. Tools showing fish-polish amount to the $33 \%$ of the used tools (Figs. 4 and 5). 


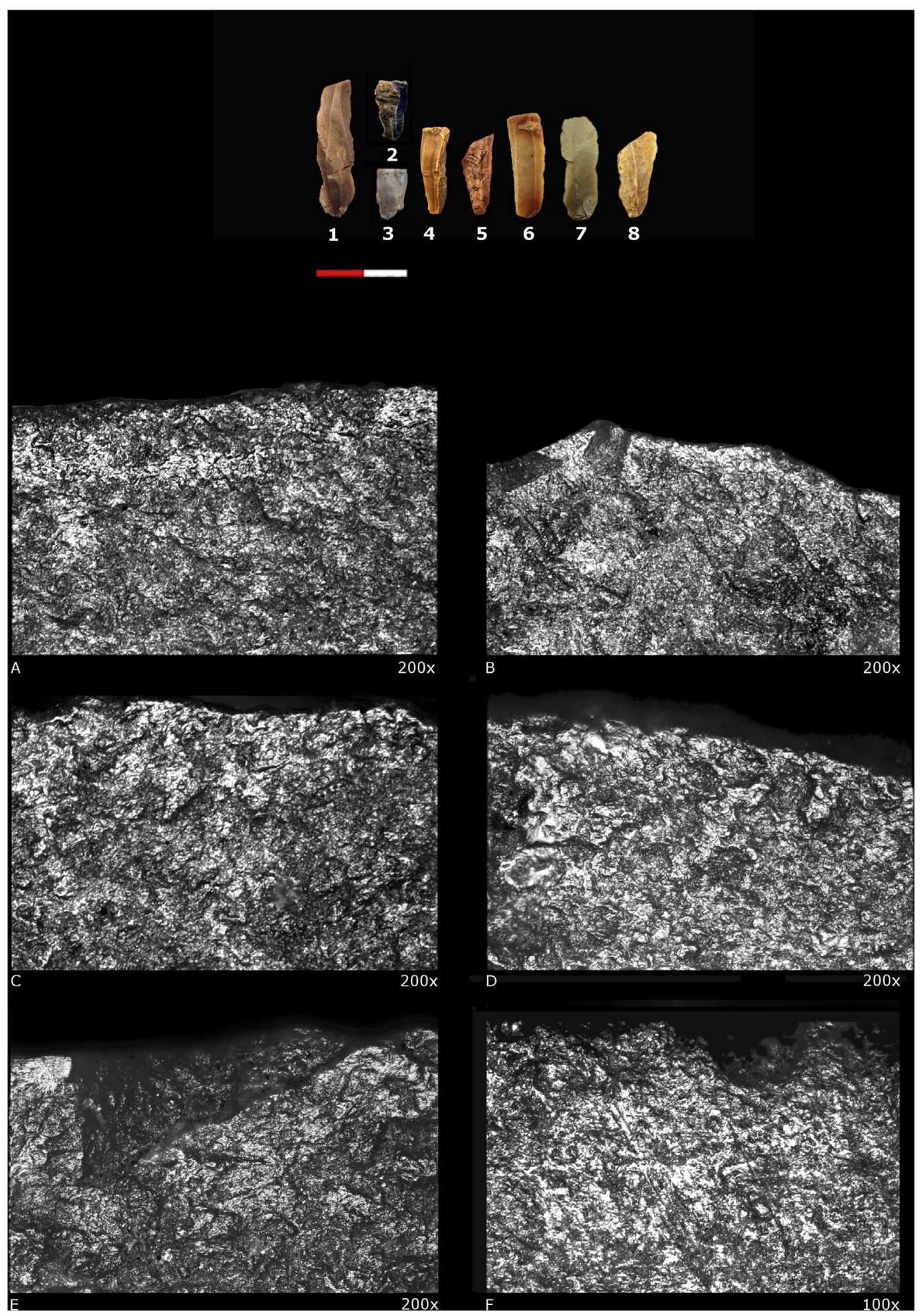

Fig. 5. Bladelets and fragments of bladelets from Vale Marim (1-5) and Vale Pincel (6-8). Lithic tools show well developed use-wears, showing feature similar to experimental traces from fish cleaning: striations and isolated spots produced by the contact with bone materials, associated to greasy and rough polishes, penetrating into the surface and within the edge-fractures. A-C) Use-wear traces from Vale Marim I, $100 \times$ and $200 \times$; D-F) Use-wear traces from Vale Pincel I, $100 \times$ and $200 \times$.

\section{Discussion}

The experimental work carried out has allowed improving the definition of a category of use-wear traces that has often been overlooked by use-wear specialists. The difficulties with the interpretation of soft materials (i.e. meat- and fish-polish) have already been outlined by several authors and special caution should be taken when interpreting such category of use-wear (Gijn, 1989). Despite such limitations, in many archaeological contexts preservation conditions allowed significant insights into prehistoric butchering practices. Since the early years, traceological works have demonstrated that, in many assemblages, it is indeed possible to recognize use-wear from working soft substances thanks to the observation of a combination of both macroand micro-wears (Plisson, 1985; González Urquijo and Ibáñez Estévez, 1994; Clemente-Conte, 1997 and more recent works). Therefore, there is no reason to suppose that while meat and butchering traces are 


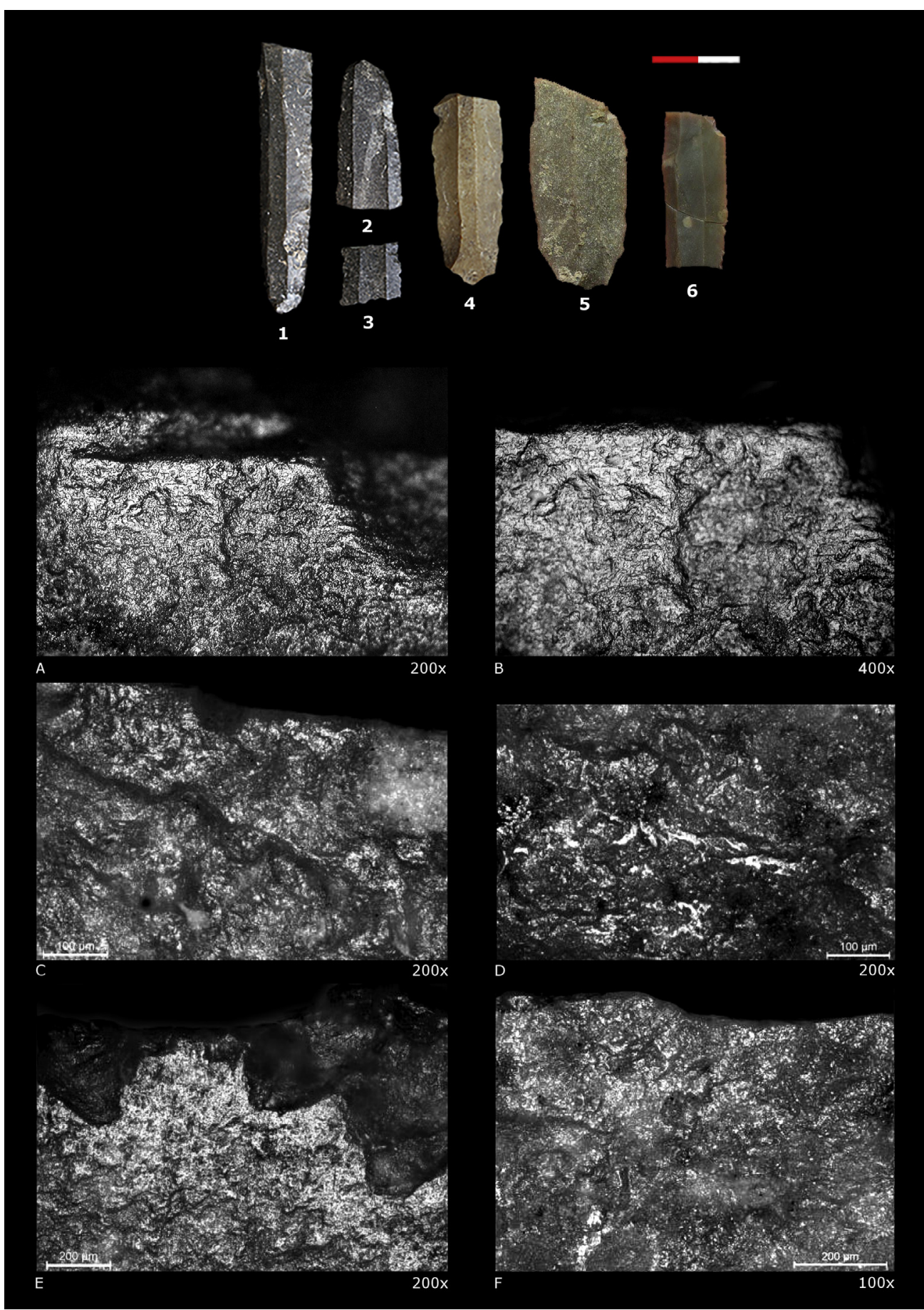

Fig. 6. Bladelets and fragments of bladelets from SET Parralejos (1-4) and La Esparragosa (5-6). Lithic tools show well developed use-wears, showing feature similar to experimental traces from fish cleaning: striations and isolated spots produced by the contact with bone materials, associated to greasy and rough polishes, penetrating into the surface and within the edge-fractures. A-B) use-wear traces from La Esparragosa, $100 \times$ and $200 \times$; C-F) use-wear traces from SET Parralejos, $100 \times$ and $200 \times$

recognisable in the archaeological specimens, fish-polishes are not.

The scarcity of fish-polish on tool assemblages from coastal prehistoric sites has been previously pointed out. There are in fact very few archaeological cases of fish-related use-wear traces, despite their distinctive character (Moss, 1983). The explanation provided by van Gijn (1989) is that in many cases fish-polish might have been bidden among the bone-cutting implements, impeding the recognition of the specific character of the task carried out. In addition, the employment of lithic tools to clean and process fish is mainly related to its preparation for conservation and storage practises (i.e. drying, smoking, salting), while it might not be necessary for its direct consumption. Therefore, even when archaeozoological evidence of fish consumption is present, it might not imply the use of specific tools for its processing. In this sense, use-wear analysis not only can provide indirect evidence of fish exploitation, but as well of the modalities and the extent of it.

Such range of topics is particularly relevant in the framework of the research currently carried out on the Mesolithic and Neolithic societies occupying the southern Atlantic coasts of the Iberian Peninsula. Archaeozoology analysis has provided evidence for the exploitation of fish in this area, since the Mesolithic (Marques-Gabriel, 2015), and 
during the course of the Neolithic (Soriguer et al., 2002). Nevertheless, the sites here analysed are characterised by a low preservation and a low number of fish remains.

Regarding Vale Pincel I and Vale Marim I the scarcity of fish remains is likely due to conservation issues. Organic materials are not preserved on both sites, probably because of soil acidity. A few charcoals and archaeozoological remains, among which a gilt-head sea bream molar teeth, have been recovered only from a few closed structures, mainly hearths, in which depositional environment was probably less acidic. In relation to La Esparragosa and SET Parralejos, they are both pit-sites and occupational layers were not preserved. Fish remains were neither stored nor rejected in the pits and fish cleaning activities were probably performed elsewhere, closer to the sea.

Data on Meso-Neolithic fishing practices can be obtained from other sites of the region. Fish remains are for example well documented in the Late Mesolithic site of Samouqueira I (Sines, Portugal), about $10 \mathrm{~km}$ south of Vale Pincel I and Vale Marin sites (Soares and Tavares da Silva, 2018). Data suggests that Mesolithic fishing economy was based on a diversity of prey, big and small. Small sharks and rays (Chondrichthyes class) are dominant. Most of them are attributable to the Triakidae family (dog shark). There were also fish of the Osteichthyes class, mainly gilt-head sea bream (Sparus aurata). Other identified species were meagre or jewfish (Argyrosomus regius - Asso, 1801) of the Sciaenidae family. Osteological remains from Serranidae and Scombridae (e.g. mackerel - Scomber scombrus - Linnaeus, 1758) were also recognized.

At the Early Neolithic site of El Retamar, located in the Bahía de Cádiz, at about $15 \mathrm{~km}$ from La Esparragosa, abundant ichthyofauna remains have been documented. Seven different species have been recovered, including fish of the Sparidae family - among which gilt-head sea bream is dominant-and, in lesser extent, epipelagic fish species among which meagre and bluefin tuna. Fish remains are mainly associated to hearth structures, and the anatomical representation suggests that some kind of processing activities were performed on-site (Ramos and Cantillo, 2009; Cantillo et al., 2010).

The results obtained from the analysis of Vale Marim I, Vale Pincel I, La Esparragosa and SET Parralejos shed new light on the understanding of fish exploitation practises (Fig. 4). The presence of a relevant percentage of traces bearing the characteristic features of fish-polish suggests that fish were not only consumed on this site, but as well processed, presumably for its conservation and storage. Use-wear analysis reveals invisible data that otherwise would not easily emerge from the archaeological records, especially in southern European contexts.

In the Mediterranean area, differently from other geographical regions, fishing and fish exploitation are discontinuously documented. Some examples are the Mesolithic sites of Vela Spila in Dalmatia (Rainsford et al., 2014), Cave of the Cyclops (Moundrea-Agrafioti, 2003), and Franchthi Cave in Greece (Rose, 1995), Dos de La Forca in the Alpine region (Coltorti et al., 2009; Crezzini et al., 2014), Grotta dell'Uzzo in Sicily (Tagliacozzo, 1993). However, there is not clear agreement whether fish represented a diet supplement or a main food source, with data strongly varying from one site to another. In addition, in most of these contexts, it is difficult to assess whether fish was caught and either consumed without further processing or processed for storage. With the introduction of agricultural and herding practices during the Neolithic, the exploitation of marine resources in general, including fish, seems to diminish, and of fish as well, eventually favouring an occasional and small-scale exploitation of species which could be caught relatively easily from coastal waters (Rainsford et al., 2014). One of the clearest evidence for a specialised exploitation of fish, including fish processing and storage practises, is provided by the submerged Pre-Pottery Neolithic site of Atlit-Yam in the northern coasts of Israel (Galili et al., 2004). Unfortunately, in none of the above-mentioned sites traceological studies have been carried out on the stone tool assemblage, and therefore it is not possible to correlate archaeozoological evidence of fish processing with any specific tool-type.

The isotopic analysis point out as well for a reduced input of marine resources on the diet during Neolithic in the Mediterranean (SalazarGarcía et al., 2017, 2018). Regarding the Portuguese Atlantic coast, isotopic data indicates a dietary shift between Mesolithic and Neolithic, with divergent dietary choices even among coexisting hunter-gatherersfishing and farming communities (Guiry et al., 2016). Nevertheless, the number of individuals analysed is still very low and geographically sparse, especially for the area concerned in this study.

Our study provides additional data in this sense, pointing out the existence of fish processing practices since the Mesolithic and continuing during the course of the Neolithic. Obtained data suggest that, in coastal areas, fish represented an important resource, exploited for its consumption, but also processed for its storage. Although the differentiation of fish-related from other butchering traces is not always easy, especially on archaeological materials, it has been possible to highlight a relevant percentage of tools showing traces interpretable as produced by fish working tasks. For Mesolithic and Early Neolithic, between $6 \%$ and $12 \%$ of the used zones are associated to fish processing, while for Late Neolithic percentages are even higher (over $30 \%$ of AUAs). This data seems to point out a continuity in subsistence practises, but our sample is still too scarce and the number of analysed sites too small to evaluate the importance of this activity on a broader economic and social perspective. Neolithisation dynamics might have followed a different path in this region in respect to other geographical areas where fishing and fish processing do not seem to play a relevant role (i.e. north-east of the Iberian Peninsula) (Mazzucco and Gibaja, 2018), even in sites located in coastal areas (Borrell and Gibaja, 2012). Other authors have already highlighted the existence of specific cultural and material features in the Neolithic of the southwestern façade of the Iberian Peninsula, confirming the idea of regionalisation or local recomposition of the Neolithic package (Manen et al., 2007). This process might be reflected as well in the adoption of different economic strategies, adapted to diverse local environmental and cultural conditions.

\section{Conclusions and perspectives}

Fish is an important resource, providing important vitamins, proteins, and minerals. It is a fairly reliable, renewable, and predictable food source. Its role in prehistoric societies is still largely unknown, and the interpretation of fishing remains controversial. Despite that, its importance at a dietary level might have been strongly varying from period to period, from area to area, and from site to site. Use-wear and residue analysis might represent additional techniques to approach such topic. Enlarging the number of studied contexts and refining the experimental and methodological framework it may be possible to open new perspectives for the study of fish processing and preparation techniques. In addition, in the framework of an ongoing project, we will try to approach fish-polish through confocal microscopy (Ibáñez et al., 2019), in order to quantitatively characterise their microtextural features and better separate them from other classes of use-wear traces, especially traces from butchering of mammals.

Chemical analysis of fat residues preserved in pottery vessels and archaeological structures are currently ongoing in the studied sites and will as well provide additional data on Meso-Neolithic cooking and food practises. In this sense, it is remarkable that at Vale Marim I, site excavators identified a domestic structure which contained Sparus aurata molar teeth and was composed of a fireplace within fire-cracked cobbles packed into sandy-grey sediment with traces of combustion remains, linked to a stoned posthole (Soares and Tavares da Silva, 2018). Despite the unfavourable conditions of organic materials preservation at the site, future analysis will explore whether this feature was related to fish conservation practises or not.

In conclusion, the role of fish resources should not be overlooked by archaeologists, despite information being often fragmentary, especially in the Mediterranean area. The study of fish-related practices (processing, storage, consumption, etc.) and of related tools, structures and residues undoubtedly represents an important field of research to be 
developed, integrating different sources and analytical methods.

\section{Declaration of competing interest}

The authors declare that they have no known competing financial interests or personal relationships that could have appeared to influence the work reported in this paper.

\section{Acknowledgements}

Part of this study has been possible thanks to the funding of the Museum of Archaeology and Ethnography of the District of Setúbal. This research has been carried out in the framework of the research project: 'Análisis de sociedades prehistóricas (del Paleolítico Medio al Neolítico Final) en las dos orillas del Estrecho de Gibraltar. Relaciones y Contactos' funded by FEDER/Ministerio de Ciencia, Innovación y Universidades/Agencia Estatal de Investigación/(HAR2017-87324-P). We thank E.Y. Girya for providing us the knapped flint for the experiments and the AGAUR of the Generalitat of Catalonia for financing the Archaeology of Social Dynamics research group of the IMF-CSIC (17SGR-995).

\section{References}

Anderson-Gerfaud, P.C., 1981. Contribution méthodologique à l'analyse des micro-traces d'utilisation sur les outils préhistoriques. Thèse de $3^{\text {ème }}$ Cycle, Université de Bordeaux I $n^{0} 1607$.

Arrighi, S., Bazzanella, M., Boschin, F., Wierer, U., 2016. How to make and use a bone 'spatula'. An experimental program based on the Mesolithic osseous assemblage of Galgenbühel/Dos de la Forca (Salurn/Salorno, BZ, Italy). Quat. Int. 423, 143-165.

Bicho, N., Umbelino, C., Detry, C., Pereira, T., 2010. The emergence of Muge Mesolithic shell middens in central Portugal and the 8200 cal yr BP cold event. J. Isl. Coast. Archaeol. 5 (1), 86-104.

Bicho, N., Cascalheira, J., Gonçalves, C., Umbelino, C., Rivero, D.G., André, L., 2017. Resilience, replacement and acculturation in the Mesolithic/Neolithic transition: the case of Muge, central Portugal. Quat. Int. 446, 31-42.

Borrell, F., Gibaja, J.F., 2012. The first neolithic communities in northeast iberia: procurement, production, and use of lithic tools at the settlement of caserna de Sant pau del camp (barcelona, Spain). J. Isl. Coast. Archaeol. 7 (3), 313-337.

Cantillo, J.J., Ramos, J., Soriguer, M., Pérez, M., Vijande, E., Bernal, D., Domínguez-Bella, S., Zabala, C., Hernando, J., Clemente-Conte, I., 2010. La explotación de los recursos marinos por sociedades cazadoras-recolectoras-mariscadoras y tribales comunitarias en la región histórica del Estrecho de Gibraltar. Férvedes 6, 105-113.

Carvalho, A.F., 2002. Current perspectives on the transition from the mesolithic to the neolithic in Portugal. SAGVNTVM Extra 5, 235-250.

Carvalho, A.F., 2018. When the Mediterranean met the Atlantic. A socio-economic view on Early Neolithic communities in central-southern Portugal. Quat. Int. 470 (Part B), 472-484. https://doi.org/10.1016/j.quaint.2016.12.045.

Carvalho, A.F., Gibaja, J.F., Cardoso, J.L., 2013. Insights into the earliest agriculture of Central Portugal: sickle implements from the Early Neolithic site of Cortiçóis (Santarém). Comptes Rendus Palevol 12 (1), 31-43.

Clemente-Conte, I., 1997. Los instrumentos líticos de Túnel VII: una aproximación etnoarqueológica. Treballs d'Etnoarqueologia, vol. 2 CSIC, Madrid.

Clemente-Conte, I., García Díaz, V., 2008. Yacimientos arqueológicos de la Bahía de Cádiz. Aplicación del análisis funcional a los instrumentos de trabajo líticos del Embarcadero del río Palmones, La mesa y La Esparragosa. In: Ramos, J., coord (Eds.), memoria del Proyecto de Investigación: 'La ocupación prehistórica de la campiña litoral y banda atlántica de Cádiz’. Aproximación al estudio de las sociedades cazadoras-recolectoras, tribales comunitarias y clasistas iniciales. Arqueología Monografías. Junta de Andalucia, Sevilla, pp. 185-198.

Clemente-Conte, I., Gyria, E.Y., Lozovska, O.V., Lozovski, V.M., 2002. Análisis de instrumentos en costilla de alce, mandíbulas de castor y caparazón de tortuga de Zamostje 2 (Rusia). InIn Clemente-Conte, I. In: Gibaja, J.F., Risch, R. (Eds.), Análisis Funcional: su aplicación al estudio de sociedades prehistóricas. BAR International Series, 1073. Archaeopress, Oxford, pp. 187-196.

Clemente-Conte, I., García, V., Ramos, J., Bella, S.D., Pérez, M., Vijande, E., Cantillo, J.J., Soriguer, M., Zabala, C., Hernando, J., 2010. The lithic tools of the La Esparragosa site (Chiclana de la Frontera, Cádiz, Spain, fourth millennium BC): a methodological contribution of the study of lithic tools for the consumption of fish. In: BekkerNielsen, T., Bernal Casasola, D. (Eds.), Ancient Nets and Fishing Gear: Proceedings of the International Workshop on Nets and Fishing Gear in Classical Antiquity: a First Approach. Servicio de Publicaciones Aarhus University Press, Cádiz, pp. 275-286.

Clemente-Conte, I., Maigrot, Y., Gyria, E.Y., Lozovskaya, O.V., Lozovski, V.M., 2013. Aperos para pesca e instrumentos para procesar pescado en Zamostje 2 (Rusia): una experimentación para reconocer los rastros de uso. In: Palomo, A., Piqué, R., Terradas, y X. (Eds.), Experimentación en Arqueología. Estudio y Difusión del pasado. Serie Monográfica del MAC, Girona, pp. 63-71.

Clemente-Conte, I., Lozovski, V.M., Gassiot Ballbè, E., Mazurkevich, A.N., Lozovskaya,
O.V., 2016. Prehistoric fish traps and fishing structures from Zamostje 2, Russian European Plain: archaeological and ethnographical contexts. In: Hardy, K., KubiakMartens, L. (Eds.), Wild harvest:Plants in the Hominin and Pre-agrarian Human Worlds. Oxbow Books, Oxford, pp. 253-272.

Coltorti, M., Pieruccini, P., Bazzanella, M., Wierer, U., 2009. Site formation processes of a mesolithic rockshelter at galgenbühel/dos de la Forca (adige valley, south tyrol, Italy). Preistoria Alp. 44, 149-157.

Cortés, M., Jiménez Espejo, F.J., Simón Vallejo, M.D., Gibaja, J.F., Carvalho, A.F., Martinez-Ruiz, F., Rodrigo Gamiz, M., Flores, J.-A., Paytan, A., López Sáez, J., PeñaChocarro, L., Carrión, J., Muñiz, A., Roselló Izquierdo, E., Riquelme Cantal, J., Dean, R., Salgueiro, E., Martínez Sánchez, R., De la Rubia de Gracia, J., Lozano, M., Vera Peláez, L., Llorente Rodríguez, L., Bicho, N.F., 2012. The Mesolithic-Neolithic transition in southern Iberia. Quat. Res. 77 (2), 221-234.

Crezzini, J., Boschin, F., Boscato, P., Wierer, U., 2014. Wild cats and cut marks: exploitation of Felis silvestris in the mesolithic of galgenbühel/dos de la Forca (south tyrol, Italy). Quat. Int. 330, 52-60.

Davis, S.J., Simões, T., 2016. In: The Velocity of ovis in Prehistoric Times: the Sheep Bones from Early Neolithic Lameiras, Sintra, Portugal, Diniz, M., Neves, C., Martins, A., O Neolítico em Portugal antes do Horizonte 2020: perspectivas em debate, Monografias da AAP, 2. Associação de Arqueólogos Portugueses, Lisboa, pp. 51-66.

Dean, R.M., Valente, M.J., Carvalho, A.F., 2012. The mesolithic/neolithic transition on the costa vicentina, Portugal. Quat. Int. 264, 100-108.

Diniz, M., Neves, C., 2018. O princípio do Neolítico no Sudoeste Peninsular (Portugal): uma leitura (breve) dos últimos 20 anos. In: Atas do VIII Encontro de Arqueologia do Sudoeste Peninsular, vol. 24. pp. 25 e 26 de outubro de 2014. Edição da CM Serpa, Serpa, pp. 315-350.

Galili, E., Lernau, O., Zohar, I., 2004. Fishing and coastal adaptations at atlit-yam - a submerged PPNC fishing village off the carmel coast, Israel. Atiqot 48, 1-34.

García Díaz, V., Clemente-Conte, I., 2011. Procesando pescado: reproducción de las huellas de uso en cuchillos de sílex experimentales. In: Morgado, A., Baena, J., García, D. (Eds.), La investigación experimental aplicada a la arqueología. Universidad de Granada, Universidad Autónoma de Madrid, Asociación Experimenta, Málaga, pp. 153-159.

Gijn, A. L. van, 1984/85/86. Fish polish: fact and fiction. Early Man News 9-10-11, 13-28.

Gijn, A. L. van, 1989. The wear and tear of flint. Principles of functional analysis applied to Dutch neolithic assemblages. Analecta Praehistorica Leidensia, vol. 22 Publication of the Institute of Prehistory.

González Urquijo, J.E., Ibáñez Estévez, J.J., 1994. Metodología de análisis funcional de instrumentos tallados en sílex. Cuadernos de Arqueología 14 Universidad de Deusto, Bilbao.

Gonçalves, V.S., Marchand, G., Sousa, A.C., 2008. Mudança e permanência do Mesolítico final ao Neolítico (Reguengos de Monsaraz, Évora, Portugal). In: Hernández, M., Soler, J.A., López, J. (Eds.), IV Congreso del Neolítico Peninsular. Museo Arqueológico de Alicante y Diputación de Alicante, Alicante, pp. 385-392.

Guilaine, J., 2017. A personal view of the neolithisation of the Western Mediterranean. Quat. Int. 470 (Part B), 211-225. https://doi.org/10.1016/j.quaint.2017.06.019.

Guiry, E.J., Hillier, M., Boaventura, R., Silva, A.M., Oosterbeek, L., Tomé, T., Valera, A., Cardoso, L.J., Hepburn, J.C., Richards, M.P., 2016. The transition to agriculture in southwestern Europe: new isotopic insights from Portugal's Atlantic coast. Antiquity 90 (351), 604-616.

Högberg, A., Puseman, K., Yost, C., 2009. Integration of use-wear with protein residue analysis - a study of tool use and function in the south Scandinavian Early Neolithic. J. Archaeol. Sci. 36 (8), 1725-1737.

Ibáñez, J.J., Lazuen, T., González-Urquijo, J., 2019. Identifying experimental tool use through confocal microscopy. J. Archaeol. Method Theory 26 (3), 1176-1215.

Iovino, M.R., 2002. Procesing fish with obsidian tool: the microwear. In: Jerem, E., Biró, K.T. (Eds.), Archaeometry 98. Proccedings Of 31 Th Symposium, Budapest, April 26May 3, 1998. Archaeolingua Central European Series 1. BAR, S 1043. Archaeopress, Oxford, pp. 203-206.

Keeley, L.H., 1980. Experimental Determination of Stone Tool Uses. A Micro-wear Analysis. Prehistory, Archaeology and Ecology Series. The University of Chicago Press.

Komšo, D., Čuka, M., 2014. Neolithic fishing at the Kargadur site near Ližnjan. In: Visentini, P., (cur) (Eds.), Adriatico Senza Confini, Catalogo Della Mostra. Museo di Storia Naturale di Udine, Udine, pp. 152-153.

Kuhn, S.L., 1989. Hunter-gatherer foraging organization and strategies of artefacts replacement and discard. In: In: Amick, D.S., Mauldin, R.P. (Eds.), Experiments in Lithic Technology. British Archaeological Reports International Series, vol. 528. Archaeopress, Oxford, pp. 33-47.

LeGall, O., Straus, L.G., Vierra, B., Altuna, J., 1992. Ichtyofaunas and seasonality at vidigal (Alentejo, Portugal). Mesolithic Miscellany 13 (2), 13-18.

López -Doriga, I.L., 2015. La utilización de los recursos vegetales durante el Mesolítico y Neolítico en la costa atlántica de la península ibérica. PhD Dissertation. Universidade de Cantábria.

Lozovski, V.M., Lozovskaya, O.V., Clemente-Conte, I., 2013. Zamostje 2 Lake Settlement of the Mesolithic and Neolithic Fisherman in Upper Volga Region. Russian Academy of Science. Institute for the History of Material Culture, Sergiev-Possad State History and Art Museum-Preserved, St. Petersbourg.

Manen, C., Marchand, G., Carvalho, A., 2007. Le Néolithique ancien de la Péninsule Ibérique: vers une nouvelle évaluation du mirage africain? In: Evin, J. (Ed.), Un siècle de construction du discours scientifique en Préhistoire : XXVIe Congrès préhistorique de France, Avignon, 21-25 septembre 2004. Société préhistorique française, Paris, pp. 133-151.

Marchand, G., 2005. Contacts, blocages et filiations entre les aires culturelles mésolithiques et néolithiques en Europe atlantique. L'Anthropologie 109 (3), $541-556$. 
Marchand, G., Manen, C., 2010. Mésolithique final et Néolithique ancien autour du détroit: une perspective septentrionale (Atlantique/Méditerranée). In: Gibaja, J., Carvalho, F. (Eds.), The Last Hunter-Gatherers and the First Farming Communities in the South of the Iberian Peninsula and North of Morocco. Universidade do Algarve, Faro, pp. 173-179.

Marijanović, B., 2009. Crno Vrilo 1. Sveučilište u Zadru, Zadar.

Marques-Gabriel, S., 2015. La ictiofauna del Holoceno Inicial y Médio de Portugal (Unpublished PhD dissertation). Facultad de Ciencias, Universidad Autónoma de Madrid.

Mazzucco, N., Gibaja, J.F., 2018. A palaeoeconomic perspective on the Early Neolithic lithic assemblages of the N-NE of the Iberian Peninsula. Quat. Int. 472, 169-171. https://doi.org/10.1016/j.quaint.2016.05.012.

Mazzucco, N., Clemente-Conte, I., García Díaz, V., Soares, J., Tavares da Silva, C., Ramos Muñoz, J., Vijande Vila, E., 2018. Insights into fish resources exploitation from the use-wear analysis of lithic tools, case-studies from the Iberian Peninsula between the $6^{\text {th }}-3^{\text {rd }}$ millennia cal BC. In: Subsistence Strategies in the Stone Age, Direct and Indirect Evidence of Fishing and Gathering. Russian Academy of Science, Institute for the History of Material Culture, State Hermitage Museu, Sanara State University of Social Sciences and Education \& Sergiev Posad State History and Art Museum Preserve, St. Petersburg, pp. 165-169.

Monnier, G., Frahm, E., Luo, B., Missal, K., 2018. Developing FTIR microspectroscopy for the analysis of animal-tissue residues on stone tools. J. Archaeol. Method Theory 25, $1-44$.

Morgado, A., Pelegrin, J., 2012. Origin and development of blade pressure production at the south of the iberian Peninsula (ca. VIth-IIIrd milenium BC). In: Desrosiers, P.M. (Ed.), The Emergence of Pressure Blade Making. From Origin to Modern Experimentation. Springer, New York, pp. 219-235.

Morin, J., 2004. Cutting edges and salmon skin: variation in salmon processing technology on the northwest coast. Can. J. Archaeol. 28, 281-318.

Moss, E.H., 1983. The Functional Analysis of Flint Implements. Pincevent and Pont d'Ambon: Two Cases Studies from the French Final Palaeolithic BAR International Series, vol. 177 Archaeopress, Oxford.

Moundrea-Agrafioti, A., 2003. Mesolithic fishhooks from the Cave of cyclope, youra. In: Galanidou, N., Perlès, C. (Eds.), The Greek Mesolithic. Problems and Perspectives. The British School at Athens, London, pp. 131-141.

Peña-Chocarro, L., Pérez Jordà, G., Morales Mateos, J., Vera Rodríguez, C., 2014. ... Y llegaron los agricultores: agricultura y recolección en el occidente del mediterráneo. Menga: Rev. Prehist. Andal. 4, 15-33.

Pérez, M., Ramos, J., Vijande, E., Castaneda, V., 2005. Informe preliminar de la excavación arqueológica de urgencia en el asentamiento prehistórico de La Esparragosa (Chiclana de la Frontera). Anu. Arqueol. Andal. III, 93-103 2002.

Plisson, H., 1985. Étude fonctionnelle d'outillages lithiques préhistoriques par l'analyse des micro-usures : recherche méthodologique et archéologique. Thèse de $3^{\text {ème }}$ Cycle, Université de Paris I.

Rainsford, C., O'Connor, T., Miracle, P., 2014. Fishing in the adriatic at the Mesolithic - Neolithic transition: evidence from Vela Spila, Croatia. Environ. Archaeol. 19 (3), 311-320.

Ramos, J., 2005. Nuevas perspectivas para el estudio del proceso de neolitización en el suroeste peninsular. El tránsito de las sociedades cazadoras-recolectoras a las tribales comunitarias. In: Arias Cabal, P., Ontañón Peredo, R., García-Moncó Piñeiro, C. (Eds.), Actas del III Congreso del Neolítico en la Península Ibérica, 5 a 8 de octubre de 2003. Servicio de Publicaciones, Santander, pp. 815-822.

Ramos, J., Cantillo, J.J., 2009. Los recursos litorales en el Pleistoceno y Holoceno. Un balance de su explotación por las sociedades cazadoras-recolectoras, tribales comunitarias y clasistas iniciales en la región del Estrecho de Gibraltar. In: Bernál Cassola, D. (Ed.), Arqueología de la pesca en el Estrecho de Gibraltar: de la Prehistoria al fin del Mundo Antiguo. Servicio de Publicaciones Universidad de Cádiz, Cádiz, pp. $17-80$.

Ramos, J., Pérez Rodríguez, M., Vijande Vila, E., Cantillo Duarte, J.J., 2006. Las sociedades neolíticas en la banda atlántica de Cádiz: valoración del contexto regional y del proceso histórico de la formación social tribal, vol. 25. Quaderns de prehistòria i arqueologia de Castelló, pp. 53-89.

Ramos, J., Pérez, M., Clemente-Conte, I., García, I., Ruíz, B., Gil, M.J., Vijande, E. Soriguer, M., Hernando, J., Zabala, C., 2008. La Esparragosa (Chiclana de la Frontera). Un asentamiento con campo de silos en la campiña de Cádiz, del IV ${ }^{\circ}$ milenio a.n.e. In: Hernández, M., Soler, J.A., López, J. (Eds.), IV Congreso del Neolítico Peninsular. Museo Arqueológico de Alicante y Diputación de Alicante, Alicante, pp. 385-392.

Ramos, J., Pérez, M., Domínguez-Bella, S., Soriguer, M., Zabala, C., Hernando, J.A., RuízZapata, B., Gil, M.J., Jimenez, D., 2010. Las formaciones sociales tribales y clasistas iniciales en la Bahía de Cádiz. Medio natural y recursos". In: Gutiérrez, J.M. (Ed.), De la Prehistoria a La Rábita y la Villa. Arqueología de Rota y la Bahía de Cádiz, Fundación Alcalde Zoilo, pp. 43-75 Cádiz.

Ramos, J., Domínguez-Bella, S., Cantillo, J.J., Soriguer, M., Pérez, M., Hernando, J., Vijande, E., Zabala, C., Clemente, I., Bernal, D., 2011. Marine resources exploitation by Palaeolithic hunter-Fisher-gatherers and Neolithic tribal societies in the historical region of the Strait of Gibraltar. Quat. Int. 239 (1-2), 104-113.

Robson, H.K., Little, A., Jones, A.K.G., Blockley, S., Candy, I., Matthews, I., Palmer, A., Schreve, D., Tong, E., Pomstra, D., Fletcher, L., Hausmann, N., Taylor, B., Conneller, C., Milner, N., 2018. Scales of analysis: evidence of fish and fish processing at Star Carr. J. Archaeol. Sci.: Rep. 17, 895-903.

Rodríguez Santana, C.G., Alberto-Barroso, V., Rodríguez Rodríguez, A., GalindoRodríguez, A., 2008. Escamas y cuernos: a propósito de asociaciones insólitas en el yacimiento del Lomo de Los Melones (Telde, Gran Canaria). In: Béarez, P., Grouard, S., Clavel, B. (Eds.), Archéologie du poisson. 30 ans d'archéo-ichtyologie au cnrs.
Hommage aux travaux de Jean Desse et Nathalie Desse-Berset XXVIIIe rencontres internationales d'archéologie et d'histoire d'Antibes. Sous la direction de Clavel Éditions APDCA, Antibes, pp. 1-14.

Rose, M., 1995. Fishing at Franchthi Cave, Greece: changing environments and patterns of exploitation. Old World Archaeol. Newsl. 18 (3), 6-21.

Salazar-García, D.C., Pérez-Ripoll, M., García-Borja, P., Pardo, J.F.J., Tortosa, J.E.A., 2017. A terrestrial diet close to the coast: a case study from the Neolithic levels of Nerja Cave (Málaga, Spain). In: García Puchol, O., Salazar-García, D.C. (Eds.), Times of Neolithic Transition along the Western Mediterranean. Springer, Cham, pp. 281-307.

Salazar-García, D.C., Fontanals-Coll, M., Goude, G., Subirà, M.E., 2018. “To 'seafood'or not to 'seafood'?" an isotopic perspective on dietary preferences at the MesolithicNeolithic transition in the Western Mediterranean. Quat. Int. 470, 497-510.

Semenov, S.A., 1964. Prehistoric Technology. Cory, Adams and Mackay, Londres.

Soares, J., 1996. Padrões de povoamento e subsistência no Mesolítico da Costa Sudoeste portuguesa. Zephyrus 49, 109-124.

Soares, J., 2013. Caçadores-recolectores semi-sedentários do Mesolítico do paleoestuário do Sado (Portugal). In: Soares, J. (Ed.), Pré-História das Zonas Húmidas/Prehistory of Wetlands, Setúbal Arqueológica, 14. MAEDS-ADS/SIMARSUL, S.A, Setúbal, pp. 13-56.

Soares, J., Mazzucco, N., Clemente-Conte, I., 2016. The first farming communities in the Southwest European Coast: a traceological approach to the lithic assemblage of Vale Pincel I. J. Anthropol. Archaeol. 41, 246-262.

Soares, J., Mazzucco, N., Tavares da Silva, C., 2017. Marine adaptations in the late mesolithic of the southwest Portuguese coast. Micro-use wear analysis of the lithic industry of Vale Marim I. Rev. Port. Arqueol. 20, 31-44.

Soares, J., Tavares da Silva, C., 1979. Alguns aspectos do Neolítico antigo do Alentejo Litoral. In: Actas da 1a Mesa Redonda 'O Neolítico e o Calcolítico em Portugal', Trabalhos do Grupo de Estudos Arqueológicos do Porto. Grupo de Estudos Arqueológicos do Porto, Porto, pp. 9-50.

Soares, J., Tavares da Silva, C., 2004. Alterações ambientais e povoamento na transição Mesolítico-Neolítico na Costa Sudoeste. In: Tavares, A.A., Tavares, M.J.F., Cardoso, J.L. (Eds.), Evolução Geohistórica do Litoral Português e Fenómenos Correlativos. Geologia, História, Arqueologia e Climatologia. Universidade Aberta, Lisboa, pp. 397-424.

Soares, J., Tavares da Silva, C., 2018. Living in the southwest Portuguese coast during the late mesolithic: the case study of Vale Marim I. J. Archaeol. Sci.: Rep. 18, 1011-1025.

Soares, J., Tavares da Silva, C., Canilho, M.H., 2005-2007. Matérias-primas minerais e mobilidade logística no Mesolítico da Costa Sudoeste. Os sítios de Samouqueira I e Armação Nova. Musa Museus. Arqueol. Outros Patrimónios 2, 47-62.

Soriguer, M., Zabala, C., Hernando, J., 2002. Características biológicas de la fauna Marima del yacimiento de 'El Retamar'. In: Ramos, J., Lazarich, M. (Eds.), El asentamiento de 'El Retamar' (Puerto Real, Cádiz). Contribución al estudio de la formación social tribal y a los inicios de la economía de producción en la Bahía de Cádiz. Universidad de Cádiz y Ayuntamiento de Puerto Real, Cádiz, pp. 193-204.

Tagliacozzo, A., 1993. Archeozoologia della Grotta dell'Uzzo, Sicilia: da un'economia di caccia ad un'economia di pesca ed allevamento. Istituto poligrafico e Zecca dello Stato, Roma.

Tavares da Silva, C., Soares, J., 2007. "Osmose Cultural” e neolitização na Préhistória europeia. A propósito da transição Mesolítico-Neolítico no Sul de Portugal. Estudos Arqueol. Oeiras 15, 37-46.

Tavares da Silva, C., Soares, J., 2015. Neolitização da Costa Sudoeste Portuguesa. A cronologia de Vale Pincel I. In: Gonçalves, V., Diniz, M., Sousa, A.C. (Eds.), $5^{\circ}$ Congresso Do Neolítico Peninsular, Estudos \& Memórias, 8. Centro de Arqueologia da Universidade de Lisboa-UNIARQ, Lisboa, pp. 645-659.

Valente, M.J., Carvalho, A.F.D., 2009. Recent developments in Early Holocene huntergatherer subsistence and settlement: a view from southwestern Iberia. In: McCartan, S., Schulting, R., Warren, G., Woodman, P. (Eds.), Mesolithic Horizons: Papers Presented at the Seventh International Conference on the Mesolithic in Europe. Oxbow Books, Oxford.

Vaughan, P.C., 1985. Use-wear Analysis of Flaked Stone Tools. The University of Arizona Press, Tucson, Arizona.

Vijande, E., 2006. Prehistoria reciente de Chiclana de la frontera. Aportación al con ocimiento de las formaciones sociales tribales y clasistas iniciales en el marco de la banda atlántica gaditana. Universidad de Cádiz. Servicio de Publicaciones, Libro electrónico.

Vijande, E., 2008. Aproximación al conocimiento de las formaciones sociales tribales en Chiclana de la Frontera y su contribución al estudio de las mismas en el ámbito de la banda atlántica gaditana. Rev. Atlántica-Mediterr. Prehist. Arqueol. Soc. 8, 87-108.

Vijande-Vila, E., Ramos-Muñoz, J., Pérez-Rodríguez, M., Moreno-Márquez, A., Cantillo, J.J., DomínguezBella, S., Almisas, S., Riquelme, J.A., Soriguer, M.C., Clemente-Conte, I., García, V., Barrena, A., Ruiz, B., Gil, M.J., Fernández-Sánchez, D., 2018. Estudio interdisciplinar de la tumba AV del asentamiento neolítico de La Esparragosa (Chiclana de la Frontera, Cádiz, España). Arqueol. Iberoam. 37, 40-47.

Villalpando, A., Montañés, M., 2009. Avance de resultados de las excavaciones arqueologicas realizadas e SET Parralejos. Rev. Atlántica Mediterr. Prehist. Arqueol. Soc. 11, 257-264.

Villapando, A., Montañés, M., 2016. El yacimiento de SET Parralejos, Vejer de la Frontera (Cádiz). Un Núcleo de Población de la Prehistoria Reciente en las Estribaciones del río Salado de Conil de la Frontera. En J. Ramos, J.J. Cantillo y E. Vijande, coord.: "Las sociedades prehistóricas y la Arqueología de Conil en el contexto de la Banda Atlántica de Cádiz". Ediciones Pinsapar, Cádiz, pp. 115-134.

Zilhao, J., 2003. The spread of agro-pastoral economies across Mediterranean Europe: a view from the far west. J. Mediterr. Archaeol. 6 (1), 5-63. 